ESRI

RESEARCH

BULLETIN

JUNE

2020
INITIAL INCIDENCE OF CARBON TAXES AND ENVIRONMENTAL LIABILITY: A VEHICLE OWNERSHIP APPROACH

\section{MIGUEL A.TOVAR REAÑOS}

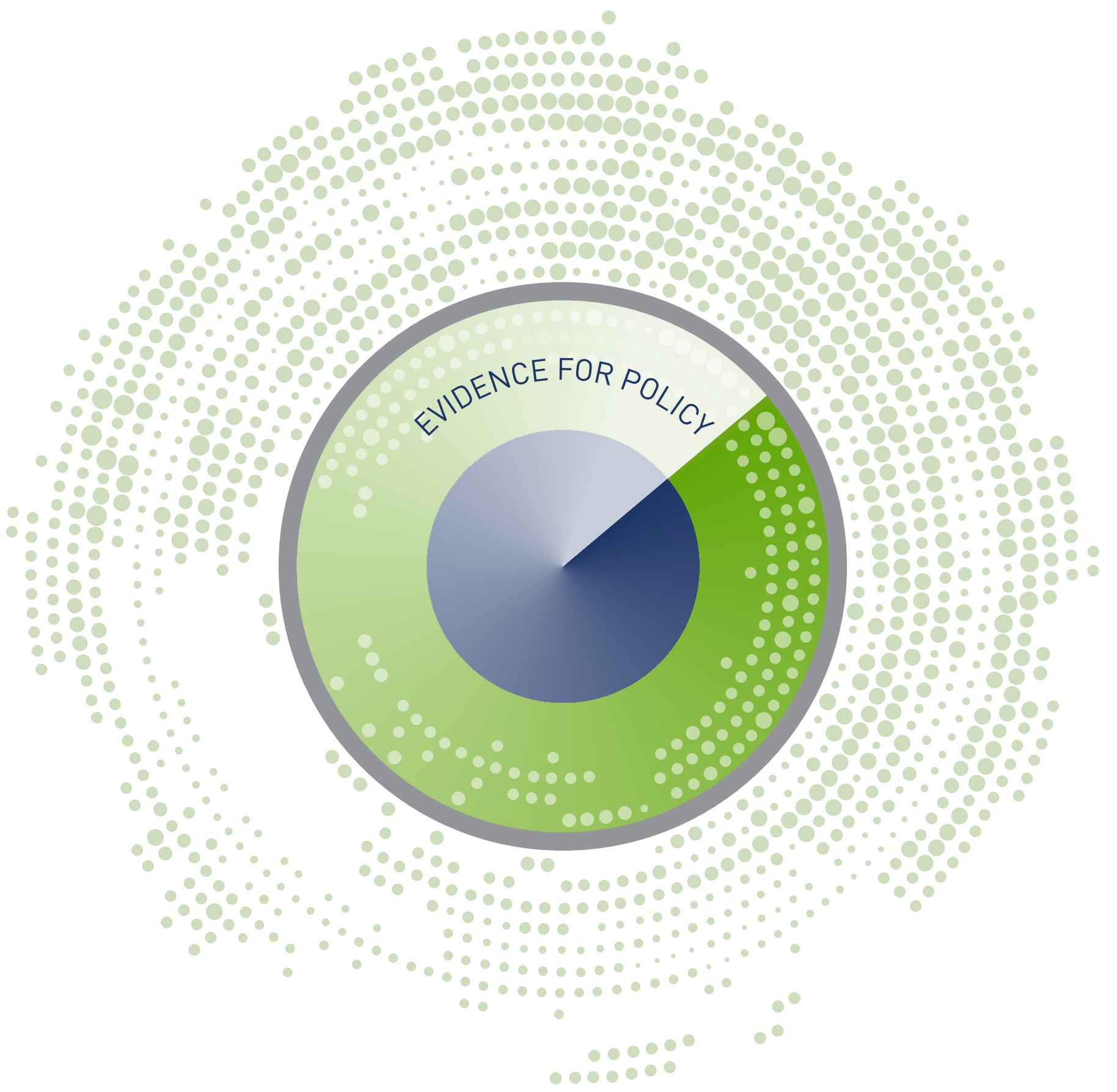




\title{
Initial incidence of carbon taxes and environmental liability: A vehicle ownership approach ${ }^{1}$
}

*Miguel A. Tovar Reaños (Economic and Social Research Institute)

\begin{abstract}
ESRI Research Bulletins provide short summaries of work published by ESRI researchers and overviews of thematic areas covered by ESRI programmes of research. Bulletins are designed to be easily accessible to a wide readership.
\end{abstract}

\section{BACKGROUND AND CONTEXT}

Decarbonizing the transport sector is key to reducing the general level of $\mathrm{CO}_{2}$ emissions. At a European level, emissions from this sector accounted for $29 \%$ of total $\mathrm{CO}_{2}$ emissions in 2012. In Ireland, transportation accounted for $40 \%$ of total $\mathrm{CO}_{2}$ emissions in 2018 . Increasing carbon taxes has emerged as a key policy instrument to reduce emissions in this sector. Existing literature shows that carbon taxes on road transport fuels can encourage drivers to take fewer car trips and encourage them to buy more efficient vehicles. However, most of the existing literature finds that low income households are disproportionately affected by carbon taxation.

Commonly used metrics for tax burden omit the fact that households' incomes measured at one point in time may not reflect their average lifetime income. Taking this into account can reduce the tax burden. In addition, it is argued that current carbon taxes do not charge drivers according to their level of attributed pollution. At present, carbon taxes do not account for all the externalities (e.g. local pollution, congestion, accidents, etc.) caused by vehicle use. This paper considers the tax burden across household types, incorporating a measure of lifetime income, and also investigates the level at which carbon taxes should be set to reflect environmental damage.

\section{RESULTS}

Using German data and a model of vehicle usage, it is found that carbon taxes are regressive (i.e., relatively higher for low income households) when there is no tax-revenue recycling. We find that when welfare losses are assessed relative to lifetime income, the regressivity of the tax decreases slightly for low income households. Additionally, a metric that accounts for the cost of air pollution is used to analyse to what extent carbon tax reflects their level of attributed pollution. This payment is partial due to the fact that air pollution is only one of

\footnotetext{
${ }^{1}$ This Bulletin summaries the findings from: Tovar Reaños, M.A., "Initial incidence of carbon taxes and environmental liability. A vehicle ownership approach", Energy Policy, Available online: https://doi.org/10.1016/j.enpol.2020.111579
} 
the externalities caused by private transportation. It is found that drivers start paying for air pollution when taxes are set at $€ 30$ per tonne. In addition, it is found that a carbon tax encourages owners of small cars to reduce $\mathrm{CO}_{2}$ emissions more than owners of larger cars.

\section{POLICY DISCUSSIONS}

The findings from this research contribute to the current debate in Ireland about designing carbon taxes. Increasing the current carbon taxes above $€ 26$ per tonne has proven to be a real challenge regarding public acceptance. This research shows that even above $€ 30$ per tonne, drivers only pay partially for the full environmental damage of vehicle usage. In addition, carbon taxes on fuel prices need to be accompanied by other policies such as mileage-based taxes, improvements in public transportation and car sharing. In Ireland a combination of carbon taxes and shifting vehicle registration (tax on purchases) and motor taxes (ownership tax) from engine size to emissions has increased the purchase of diesel vehicles which normally are larger vehicles. This has reduced the tax revenue on vehicle registration and ownership, shifting the tax burden from car ownership to car use. This calls for a better design and combination of policy instruments to set the right tax addressing environmental damage and equity issues.

In order to achieve a socially acceptable policy, this must combine the 'ability to pay' and 'polluters pay' principles. These principles can be achieved by designing lump-sum transfers to low income households taking into consideration their environmental liability. 
Whitaker Square,

Sir John Rogerson's Quay,

Dublin 2

Telephone +353 18632000

Email admin@esri.ie

Web www.esri.ie

Twitter @ESRIDublin 